\title{
Egg laying pattern and the egg morphology of an ischnoceran louse, Goniocotes jirufti (Ansari, 1947) parasitizing black partridges, Francolinus francolinus (Phthiraptera: Ischnocera)
}

\begin{abstract}
Aftab Ahmad
Estuarine Biology Regional Centre, Zoological Survey of India, Gopalpur on-sea, Ganjam (Odisha), India

E-mail: draftab.lifescience@rediffmail.com

Abstract

The present report furnishes information on the egg laying sites, the pattern of egg laying and the nature of egg shells of an ischnoceran louse Goniocotes jirufti parasitizing black partridges, Francolinus francolinus. The louse prefers to lay eggs on the feathers belonging to back and breast region of the host. The eggs are laid on lateral plumulacious portion of the vane. The egg shell is ovoid in shape and the egg chorion is free from sculpturing and apophyses.
\end{abstract}

Keywords: Goniocotes, Ischnocera, Lice, Mallophaga, Oviposition, Phthiraptera

\section{Article Info}

DOI:10.31018/jans.v10i3.1714

Received: April 26, 2018

Revised: June 3, 2018

Accepted: June 25, 2018

\section{How to Cite}

Ahmad, A. (2018). Egg laying pattern and the egg morphology of an ischnoceran louse, Goniocotes jirufti (Ansari, 1947) parasitizing black partridges, Francolinus francolinus (Phthiraptera: Ischnocera). Journal of Applied and Natural Science, 10(3): $838-840$

\section{INTRODUCTION}

Phthirapteran ectoparasites are oviparous insects. They glue their eggs to the feathers/ hairs of the host with a kind of cementing material secreted by the glands encorporated in their lateral oviducts. The hatched eggs remain permanently glued to the feathers/hair of host throughout lifetime. Since certain avian lice have tendency to lay their eggs in protected areas of host body (in order to escape the destruction from preening/grooming by the host) information about the egg laying site and the oviposition pattern of lice are necessary to facilitate the collection of eggs for recording their in vitro biology. Specific studies on the subject have rarely been made. Workers like, Foster (1969), Nelson and Murray (1971), Nelson (1972), Surman et al. (1998), Saxena et al. (2000), Tyagi et al., 2009, Kumar et al. (2003 and 2006), Gupta et al. (2004), Ahmad et al. (2010), Rajput et al. (2010), Agarwal et al. (2011), Saxena et al. (2012), Ahmad et al. (2016) and Rana et al. (2018) have commented on the sites of oviposition and egg laying patterns of phthirapteran ectoparasites infesting selected avian hosts. In the present study an attempt has been made to provide information on egg laying sites and oviposition patterns of an ischnoceran louse, Goniocotes jirufti infesting black partridges, Francolinus francolinus.

\section{MATERIALS AND METHODS}

Four infested birds (Black Teeter, F.s francolinus) were examined under Magnascope (six inches diameter lens, fitted with circular light) after tying the legs. The body of bird was arbitrarily divided into nine regions. The number of eggs of $G$. jirufti observed in each region was recorded in tabular manner. Total number of eggs found in each region was divided by the grand total of eggs to determine the percentage of eggs laid region wise (on the lines adopted by Kumar et al. 2006). Feathers bearing fresh eggs were examined under Stereozoom Trinocular Microscope to record the egg laying pattern. Few eggs were gently teased out of feather for Scanning Electron Microscopy. For Scanning Electron Microscopic studies, fresh eggs were fixed in a $2.5 \%$ Gluteraldehyde, passed in Phosphate buffer, critically dried and mounted on double sided tape, gold coated and viewed under SEM (Mode Leo VPP 435).

\section{RESULTS AND DISCUSSION}

The egg of G. jirufti is ovoid in shape (Fig.1). Its opercular disc bear faint hexagonal marks but egg chorion is devoid of sculpturing or apophyses. The egg shell remains glued to the feather through its basal end (stigma) with the help of cementing material. G. jirufti exhibits wide spread oviposition sites on the host body. Maximum percentage of eggs were found on feathers belonging to back $(50 \%)$, followed by breast (36\%). Thus, above two regions carried $86 \%$ of the total eggs. The percentage of eggs found on abdomen $(6 \%)$, neck (4\%), nape $(2 \%)$, legs $(1 \%)$ and tail $(1 \%)$ was too 
Ahmad, A. / J. Appl. \& Nat. Sci. 10 (3): 838 - 840 (2018)

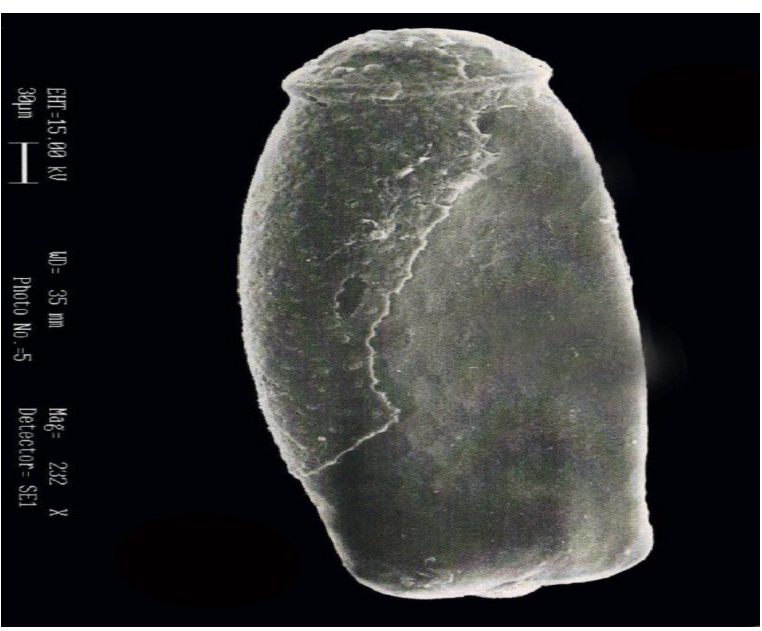

Fig.1. SEM photograph of the entireeggshell of G. Jirufti.

low. Feathers belonging to head and wings were found completely devoid of eggs. Eggs of G. jirufti are laid on the lateral plumulacious portion of the vane. Eggs remain scattered irregularly and are inclined at $20-30^{\circ}$. Maximum numbers of eggs on single feather has been noted as 08 .

Information on the egg laying sites and egg laying pattern of three phthirapteran species infesting orange crowned warbler, Vermivora ocelata (Foster, 1969), four species occurring on domestic pigeon, Columba livia (Nelson and Murray 1971, Saxena et al., 2000), one species parasitizing mallard duck, Anas platyrhynchos (Kumar et al., 2003), two species occurring on red avadavat, Amandava amandava (Gupta et al., 2004), eight species occurring on domestic fowl, Gallus gallus domesticus (Kumar et al., 2006), two species parasitizing cattle egret, Bubulcus ibis (Ahmad et al., 2010) and two species found on red whiskered bulbul, Pycnonotus jocosus (Saxena et al., 2012) have been provided by the workers. Marshall (1981) has indicated that few species prefer to lay eggs on those areas of body which the host finds relating difficult to preen. Some species lay eggs on restricted oviposition sites while other exhibit wide spread oviposition sites. The phenomenon of site shift in the egg laying sites as a result of competition between simultaneously occurring species has also been indicated by Nelson (1972). A look on literature indicates that there is no published information on the egg laying pattern and egg morphology of any lice occurring on patriges. $G$. jirufti lays most of the eggs on the feathers of back and breast region (on the lateral plumulacious portion of the vane). The egg chorion is quite smooth and devoid of sculpturing or apophysis.

\section{Conclusion}

There is no published information on the egg laying pattern and egg morphology of any lice occurring on partridges. The present report provides first information on the egg laying sites, oviposition pattern and the egg shell architecture of the egg of an ischnoceran louse Goniocotes jirufti infesting black teeter Francolinus francolinus.

\section{ACKNOWLEDGEMENTS}

A deep sense of gratitude is expressed to the Director of Zoological Survey of India, Kolkata for providing opportunity and facilities for the execution of this work. Author is thankful to the officer in -charge Dr. Anil Mohapatra, Scientist D for extending his valuable and affectionate guidance, for suggesting the problem and providing all kinds of facilities.

\section{REFERENCES}

1. Agarwal, G.P., and Ahmad, A. (2011). The egg of Laemobothrion Maximum (Amblycera: Phthiraptera). Spl. Issue. Zool. Soc. India, 1: 37-40

2. Ahmad, A., Khan, V., Badola, S., Arya, G., Bansal, N., and Saxena, A.K. (2010). Population Characteristics and the nature of egg shells of two phthirapteran species parasitizing Indian cattle Egrets. J. Insect. Sci, 10:1-7

3. Ahmad, A. (2016). The eggshell morphology of Rallicola unguiculatus Piaget, 1880 (Ischnocera: Phthiraptera). J.Parsit. Dis, DOI 10.1007/s12639-016 -0851-9

4. Foster, M.S. (1969). The egg shell of three species of Mallophaga and their significance in ecological studies. J.Parasitol, 55 (2): 453-446

5. Gupta, N., Kumar, S., Saxena, A.K. and Bisht, K.L. (2004). Aspects of oviposition of an ischnoceran (Brueelia sp.) and an amblyceran (Myrsidea amandava) lice (Phthiraptera). National Seminar on Zoology and Human Welfare. Dr. Shyama Prasad Mukherjee Government Degree College, Phaphamau, Allahabad, 204-210

6. Kumar, S., Badola, S., Singh, S.K., Gupta, N. and Saxena, A.K. (2003). Aspects of oviposition in duck louse, Anaticola crassicornis (Insecta, Ischnocera: Phthiraptera). Par. Dis, 111-117

7. Kumar, S., Gupta, N. and Saxena, A.K. (2006). Egg laying patterns of phthirapteran ectoparasites infesting domestic hen, Gallus gallus domesticus. J. Parasit. Appl.Anim.Biol, 15 (1 \& 2): 11- 15

8. Nelson, B.C. and Murray, M.D. (1971). The distribution of Mallophaga on the domestic pigeon (Columba livia). Int.J.Parasitol, 1: 21-29

9. Nelson, B.C. (1972). A revision of the New world species of Ricinus (Mallophaga) occurring on Passeriformes (Aves) Berkley. Los Angeles, London, University of California Press

10.Marshall, A.G. (1981). The ecology of ectoparasitic insects. Academic Press, London. $417 \mathrm{p}$

11.Rajput, S., Gupta.N., Saxena, A.K. and Joshi, V.D. (2010). Microtopography of the egg shell ofMenacanthus eurysternus(Phthiraptera: Amblycera). J. Appl. Nat. Sci, 2: 111-113

12.Rana, S.P., Bhardwaj, S.K. and Saxena, A.K. (2018). In vitro biology of pigeon louse Colpocephalum turbinatum (Amblycear: Phthiraptera). J. Appl. Nat. Sci, 10(2): $770-772$

13.Saxena, A.K., Singh, S.K., Surman., Kumar, A. and Badola, S. (2000). SEM studies on the microtopogra- 
Ahmad, A. / J. Appl. \& Nat. Sci. 10 (3): 838 - 840 (2018)

phy of eggs of four pigeon lice (Phthiraptera, Insecta). Rivista di.Parasitol, XVII (LX1) N.3: 351-358

14.Saxena, A.K., Arya, G. and Bansal, N. (2012). Egg laying site and oviposition pattern of two phthirapteran species parasitizing red whiskered Bulbul (Pycnonotus jocosus). Turkish. J Parasitol,36(3): 166 -168. DOI: $10.5152 /$ tpd.2012.39
15.Surman., Singh, S.K., Saxena, A.K. and Kumar, A. (1998). Aspects of Oviposition in the poultry shaft louse, Menopon gallinae (Phthiraptera: Amblycera). Rivista di.Parasitol, XV (LIX) N-2 :212-218

16.Tyagi, S., Gupta, N., Joshi, V.D., Rashmi, A., Arya, G. and Saxena, A. K. (2009). The eggshell morphology of Heterodoxus spiniger infesting dog Canis familiaris (Boopiidae Mallophaga). J. Appl. Nat. Sci, 1(1): 71-73 